\title{
Revealing Ukuwah-Based Islamic Accounting Practices
}

\author{
A. Musyarrafah Vetriyani ${ }^{1}$, Alimuddin ${ }^{2}$, and Syamsuddin ${ }^{3}$ \\ Magister of Accounting, Faculty of Economic and Business \\ Hasanuddin University, Makassar, Indonesia.
}

\begin{abstract}
Abstarct - This study aims to determine the existence of ukhuwah-based sharia accounting practices at 212 AlFatih Villa Mutiara Mart which is a sharia-based modern retail shop located on Jl. Ir. Soetami, Bringkanaya District, Makassar City. This research is a research in the field of qualitative ethnometodology. The ethnomethodology method is one of the approaches in qualitative research that seeks to describe how human behavior or actions within the "culture" are related to the interaction patterns that occur and the background of their actions, and the study leads to an effort to understand the meaning that exists in the life of an organization or group. the people inside. The results show that the ukhuwah-based sharia accounting practice is very distinctive, built by the 212 alumni community, which is a group of Islamic people who steadfastly defend their religion. So that the characteristics of accounting do not escape the cultural values that are covered by Islamic values, namely help, trust and affection and love. The syariah accounting system is based on brotherhood in the midst of the development of accounting in Indonesia, and incidentally was born from the womb of the Muslim community.
\end{abstract}

Keywords:- Islamic Accounting, Ukhuwah, 212 Mart AlFatih.

\section{INTRODUCTION}

The economic system of the Indonesian nation has basically been stated in the 1945 Constitution Article 33 paragraph 1 which states that "The economy is structured as a joint effort based on the principle of kinship". In paragraph 4 states that "The national economy is organized based on economic democracy with the principles of togetherness, fair efficiency, sustainability, environmental insight, independence, and by maintaining a balance of progress and national economic unity". From the explanation of the Constitution, it implies that we think and determine what kind of economic system is in accordance with the environment without leaving the applicable regulations. Economic activities never escape from a system for recording financial transactions or accounting activities that are tailored to the needs of an entity. One example is the State of Indonesia with its various cultures, of course it can give birth to accounting from Rahim, the motherland. Hanif, et al (2015) who conducted research on Padang restaurants produced research on the form of accounting for the results of the mato system as a consequence of the concept of the meaning of Padang culture.

Accounting science is not only experiencing developments in the social and cultural realm of society. Accounting is also developing in the realm of Islam, where the science of accounting is influenced by elements of Islamic law which are used as a tool to carry out orders from Allah SWT to record business transactions. In the history of Islamic development, accounting practices, especially sharia accounting, have been implemented since the time of the Prophet Muhammad, to be precise after the formation of the Islamic State in Medina and then continued by the Khulafaur Rashidin. At that time accounting laws were formed which were applied to individuals, associations (syarikah). ) or companies, waqf accounting, rights to prohibit the use of assets (hijr), and the state budget (Abdul, 2004:108). Islam views accounting as not just a value-free science for recording and reporting financial matters, but also as a tool for carrying out Islamic values in accordance with applicable sharia provisions. With the development of accounting science in the realm of society and the realm of Islam, it implies that we have an Islamic organization that is thick with spiritual values, namely 212 communites, at 212 Mart which began to develop in Indonesia. Starting from the 212 action on December 2, 2016, which was centered on the grounds of the National Monument in the Indonesian capital, hundreds of thousands of Muslims flocked to come and gather because of the call of conscience, the spirit of friendship and the strength of ukhuwah Islamiyah. Starting from this event, a Muslim community was formed and jointly developed a sharia-based retail business. One of the outlets in the Makassar area is 212 Mart Al-Fatih Villa Mutiara, located in Bulurokeng Village, Biringkanaya District, Makassar City.

In an operational technical order, Islamic accounting is an instrument used to provide useful accounting information for interested parties in making economic decisions. The description of the economic decisions produced by sharia accounting is characterized as follows: using ethical values as the basis for accounting buildings, giving direction to, or stimulating the emergence of ethical behavior, being fair to all parties, balancing selfishness with altruism, and having concern for the environment (Triyuwono, 1996: 44). Based on this explanation, this research is focused on ukhuwah-based sharia accounting practices applied to 212 Mart Al-Fatih Villa Mutiara, namely how the actors in the retail store business entity 212 Mart interpret ukhuwah in daily accounting practices and 
how the implications are obtained from the system. Therefore the research question in the context of this research is How is the ukhuwah-based sharia accounting practice that occurs in the modern retail store 212 Mart AlFatih Villa Mutiara?

\section{RESEARCH METHODS}

This study is a qualitative study to understand accounting practices based on love. Creswell (2013) defines qualitative research as a method for exploring and understanding the meaning that some individuals or groups of people think come from social or humanitarian problems. The qualitative approach in research is based on a holistic world view and rests on the three facts that, Joubis et al (2011), first, there is no single reality. That is, qualitative research recognizes plural reality. Second, reality is based on different perceptions for each person and changes over time. Apart from pluralism, reality in a qualitative approach is also dynamic, depending on how humans interpret it and changes over time as the context of human life changes. These three things are known to have meaning only in a particular situation or context. This means that meaning is present only when it is perceived by humans in the situation or context in which it is involved

\section{$>$ Research Location}

This research was conducted at a modern sharia-based retail store 212 Mart Al-Fatih Villa Mutiara, located in Bulurokeng Village, Biringkanaya District, Makassar City, Indonesia. The 212 Mart retail outlet in the Makassar region is one of the 167 outlets spread across various regions in Indonesia. The brand with this number originated from a spectacular event in Indonesia, to be precise December 2, 2016, a peaceful action movement consisting of millions of Muslims based in Jakarta as the capital of Indonesia emerged. From there, a sharia-based retail outlet which is now known as 212 Mart was born. Initial initiation of Muslims who took part in the 212 action. Finally, the 212 Sharia Cooperative was triggered on January 20, 2017, which in turn set up the 212 Mart retail outlet.

\section{$>$ Data Collection Methods}

Data collection is a systematic and standard procedure for obtaining the necessary data. Data collection methods in this study are direct observation, interviews, and documentation. In accordance with the spirit of qualitative research, researchers make observations through interaction with people related to the research focus for the purpose of understanding, exploring, and criticizing their views and experiences to obtain the necessary information or data. This study uses some data that can be analyzed further. The data source which is the subject where the data is obtained includes primary data and secondary data. The selection of informants in this study was carried out by means of purposive sampling, where the informant is a person who is considered to have a deep understanding of the social situation of the object of research and is able to provide the required information. The researcher begins by searching for a gate keeper, that is whoever is the first person to receive researchers at the location of the object of research who can provide clues about who can be interviewed or observed in order to obtain information about the obect of Bungin's research (2007)

\section{$>$ Data Analysis}

In studying daily activities that are agreed upon with group members, Garfinkel (2010) defines three stages of analysis, namely: The first stage: Indexicality analysis. This stage is the stage for finding and understanding the themes agreed upon by the group of small business actors. At this stage the researcher will create theme indexes through the expressions and body language of the 212 Mart Al-Fatih Villa Mutiara business entities.

Second stage: Reflexifity analysis After the researcher makes observations and finds the indexicality expression, the writer will examine the reflexivity of the expression. The third stage: Contextual Action Analysis. The third stage of the ethnometodological study in this research is to reveal practical daily activities that are recognizable and can be reported (visible). The crown of ethnomethodology research is an explanation of the order and relationship between the expression of indexicality, the rationalization of the expression of indexicality and will end up in an action of indexicality.

Fourth stage: Presentation of Common Sense Knowledge of Social Structures. This research boils down to understanding social structure patterns. From this ethnometodology, we researchers will get an overview of the index carried out in daily life and community agreement. From the results of this description, understanding the relation between index and reflexivity will reveal the action of indexicality that is formed. Ultimately this understanding leads to general culture. So it is clear what are the impacts of the ukhuwah basis on Islamic accounting practices and how the benefits are obtained.

\section{RESULT}

Based on data analysis and observations made, the results of this study indicate a description of the value of ukhuwah in the Islamic accounting practice of modern retail stores 212 Mart Al-Fatih as a manifestation of a brotherhood full of spiritual values that is built up between them. In looking for its form, Islamic accounting departs from an assumption that accounting is an entity that has two directions of strength. That is, accounting is not only shaped by its environment, including human behavior using accounting information (Morgan, 1988). From this assumption it can be seen that accounting has great power to influence human behavior (Morgan 1998: Francis, 1991).

By creating a certain form, Islamic accounting is expected to stimulate human behavior into humanistic behavior. This kind of situation will further strengthen selfawareness of human nature itself. Self-awareness of human nature is also the basis for giving emancipatory value to Islamic accounting. This means that Islamic accounting does not want any form of domination or oppression of one 
party over another, in line with this Kuntowidjojo (1991: 289) says we unite with those who are poor, those who are trapped in a technoratic consciousness, and those who are displaced by giant economic forces. . Together we want to free ourselves from the shackles that we have built ourselves. In other words, the information emitted by sharia accounting sows the winds of liberation within the sphere of brotherhood. He is no longer concerned with one party and underestimates the other as seen in modern accounting, but instead he stands in a fair position.

\section{$>$ Attitude of Help that Paired Sharia Accounting Harmonies}

The test results show that ukhuwah-based sharia accounting in helping behavior is the hallmark of the mudharabah principle. In business transactions the mudharabah principle of business people 212 Mart AlFatihVilla Mutiara with partners that sometimes someone has assets but does not know how to manage or trade. On the other hand, there are people who do not have assets but are competent in managing them. Therefore, this mudharabah contract affirmation indirectly affirms the relationship between two parties who need each other. Funding with the principle of mudharabah is the essence of helping each other and meeting other needs without neglecting the principles of trust and trust they receive(Musdiana,2015).

The establishment of the 212 Mart minimarket is one of the efforts of Muslims as a suggestion for finding halal sustenance. Minimarket 212 mart is different from mini market in general. Minimarket 212 Mart has many owners and is not stuck with just one company or individual. 212 mart was founded in congregation with the principle of profit sharing Mudharabah. 212 MartAl-FatihVilla Mutiara, was founded with a total turnover of Rp. 698,000,000, which originated from 135 members, 100 of whom are registered as members of the 212 sharia cooperative in Central Jakarta (Investor data base and a member of 212 Mart Al-Fatih Villa Mutiara). Each member makes an investment according to their ability at a nominal value of Rp. 500,000 to Rp. $20,000,000$. in the cooperation agreement, business benefits obtained from business activities after deducting zakat by $2.5 \%$, Islamic syiar intended for reciting teachers and ulama by $2.5 \%$, social funds intended for educational institutions such as tahfidz institutions or assistance to disaster victims in the amount of $2.5 \%$, education and research are earmarked for employee development by $2.5 \%$ and for business development funds by $20 \%$.

"Investors who join are investors who have met three conditions, have great determination in doing business but are constrained by capital, have a strong commitment to the development of the Islamic economy and have the same vision and mission harmony" Pak Agus

Indexicality analysis in the above expression states that the terms are "conditions" that must exist in order to be competent as a business partner. While the analysis of the reflexivity of the terms expression, namely, in choosing a business partner requires a selective attitude, especially in the economic principle of congregation, that the harmony of the same goals is very important for harmony in the jama'ah.

The contract agreement that was mutually agreed upon between the managers of 212 Mart Al-Fatihvilla Mutiara and the owner of the capital is set out in a mutually signed agreement. Although the scope of help in the attitude of the brotherhood. Recording and written contract agreements must still be done, because in essence transactions that occur in sharia provisions must be clear and recorded. The funds that are managed are what give rise to the slogan of mandate in the 212 Mart brand, a mandate which means that you must be entrusted with a professional in business. So in this cooperative partner relationship, the ummah should keep the Islamic brotherhood from breaking up because the establishment of the 212 Mart has a business aspect. people remain careful with always prioritizing the ukhuwah aspect compared to the business aspect. In a quite long conversation with Pak Ramlan, one of the important things that I underline from his statement is that:

"We have to be professional but don't let it break. Because building a community is easy, but we have to stay solid in the future while growing this 212 Mart "(Pak Ramlan)

The indexicality of this interview quote that professionals in building a business need special intelligence to run it deeper. This interview expression reflexivity is to build a business, build the trust of every element related to the business. Trust is one of the outputs of professionalism. No matter how professional you are, how much trust you will get. So that business continuity really depends on how strong you are to maintain professionalism, continued Pak Ramlan.

The profit ratio is distributed according to the agreement period, which is every 6 months (one semester), so that the Profit / Loss Calculation is carried out every 6 months. With the provision that all capital owners deposit their investment funds at the beginning of the agreement, namely before the establishment of the 212 Mart Al-Fatih Villa Mutiara shop. And there is no additional investment capital for the duration of the agreement, namely for a period of 5 years the mudarabah partner agreement is agreed upon.

The existence of a concept like this means that the owner of the capital and the manager have implemented mutual help. Helping out is one of the values contained in Islamic economics. Helping the weak, helping people who need help is a necessity. Islamic accounting actors are required to be able to help their siblings get out of the problems they are facing. Helping people who still enjoy usury towards an Islamic system is also categorized as part of the value of helping. 


\section{$>$ Trust in Sharia Accounting Manifestations}

The test results show that the belief referred to in the manifestation of sharia accounting is a universal basic principle inherent in Islamic accounting, namely the value of accountability, fairness, and truth. According to letter Al-Baqarah paragraph 286, that every transaction must be recorded correctly. The concept of responsibility is related to the concept of trust, which is maintaining trust and being honest in every human activity. The implication of this concept in accounting is that everyone involved in business practices must be accountable for the actions taken. The form of written responsibility for these actions in accounting is financial statements.

212 Mart financial statements are created to control store operations. Accurate and timely financial reports, of course, make it easier for the managers of 212 MartAlFatih to make strategic business decisions. 212 MartAlFatihini's financial reports are well prepared. Financial reports are made with an integrated modern system, starting from operational activities, capital, opening balances, the ending balance and other information are recorded accurately and neatly. All this is recorded to avoid missing, damaged, or undetected stock of items. Then routinely report to all capital owners through the whatsaap group, starting from daily operational activities, technical problems, damaged goods and food or beverages that has expired, so it must be removed from the inventory records.

"Every month we also distribute through theWahtsaap group monthly financial reports, but only 6 months of evaluation reports will be conducted". Bu Madianah

The indexical analysis of the interview expression is to be transparent to the owner of the capital on the store's monthly operational reports. Meanwhile, the reflexivity analysis of the expression. Efforts to maintain the trust of capital owners, financial statement records, along with all records of store operations are routinely distributed through the media group as a communication forum for business continuity.

The accountability report is the manager's obligation to be submitted to members every two times a year to be studied and discussed and then used as a reference in drawing conclusions for the sake of interest and strengthening in the 212 MartAl-FatihVilla Mutiara outlet. The financial reporting period is carried out every 6 months by the manager, usually the profit and loss report is distributed in the whatsaap investor group 212 Mart AlFatih, apart from this being stated in the cooperation agreement, this reporting also aims to carry out financial transparency to increase trust and increase supervision of capital owners.

In order to maintain the brotherhood that has existed among accounting actors, it is emphasized on the importance of accounting information that has the ability to influence users to behave ethically in doing business. Accounting that has this capability is sharia accounting. With this sharia accounting information it is expected that user behavior will be a trigger for the creation of an ideal business reality. Ukhuwah describes the spiritual values that are included in the reporting of accountability, this conception actually provides a guide on how sharia accounting should be practiced. Sharia accounting is able to stimulate the creation of a monotheistic economic and business reality.

\section{$>$ Compassion and Love Bringing Wholeness to Islamic Accounting}

Love and love from a search for the meaning of ukhuwah found Islamic accounting activities at 212 MartAl-FatihVilla Mutiara, namely by carrying out various social activities, such as helping victims of earthquakes, landslides and flood victims around the Makassar area, these assistance funds were obtained from provision for social funds of the mutually agreed production sharing agreement. In addition, love and love comes from the sincerity of the investors, some of whom do not take the promised profit sharing but rather prioritize additional social funds. Even though the essence of alms for them as a bridge to gain benefits in the world and the hereafter has been carried out regularly, namely channeling personal funds through the Friday alms program which is carried out every week, the proceeds of course come from the alms of 212 Mart managers and investors, intended for fulfilling needs. the main under privileged people, nursing homes, tahfidz institutions and others. And this program also directly increased sales at 212 MartAl-FatihVilla Mutiara outlets, which came from large-scale purchases of basic foodstuffs to be distributed on the blessing Friday program. They believe that sincerity will reap blessings, working together to build a business entity is an effort to obtain the blessings of living together, through a blessed and lawful business process.

In line with the value of Ukhuwah in Islam as described by Alimuddin (2011), it requires that: first, all resources are used to meet the primary needs of mankind to ensure sufficiency and a respectable standard of living for everyone, which is consistent with human dignity as the caliph of God. The second requirement is that the fulfillment of our siblings' needs must be obtained from a good and clean source (halal), this means that all current people fulfill their primary needs through good (halal) goodness and propriety.

"There are also some investors who only use the profits distributed in the allotment of social funds, blessing Friday programs, some are taken, some are also for business development" Kartini Lemang

The indexical analysis of the interview expressions shows that the profit sharing obtained is not for oneself, but for others who need it more. The meaning of reflexivity implied by this expression shows that moral actions such as sending aid, whether medical, food, or clothing are the principles of value that strengthen us as moral humans. This shows that we have an obligation to uphold those sacred actions which are essentially useful for ourselves as 
well as for others. This is where the values of affection get their presence.

In this picture, accounting requires the supplementation of spiritual values that can balance its masculine character. By incorporating spirituality values in the form of affection and love, it can nudge the selfishness of accounting which is colored by its capitalistic nature. Accounting really plays a very important role in influencing and shaping organizational change (Hopwood, 1990). Humans are at the center of awareness of the importance of accounting which is more humanistic and contains affection and love. Love points that encourage and strengthen on every line and keep a balance between the affairs of this world and the hereafter.

\section{DISCUSSION}

It is a phenomenon of the development of accounting as a societal ideology in implementing practices in life that lead to socioeconomic conditions. Accident concessions in accounting indicate accounting as a dynamic concept, adapting in all times and spaces as the complex realities of human life, not static but evolving continuously. Based on the description of Islamic accounting practices based on ukuwah 212 Mart Al-Fatih, from each practice action produced there are values that surround it, social values and spirituality that inhabit and interact in the processes of community life that lead to the reality of ukhuwah-based accounting practices. practiced by a Muslim community.

These values are the value of help, the value of trust and the value of affection which are summarized in table 1 .

\begin{tabular}{|c|c|c|}
\hline No. & $\begin{array}{c}\text { Generated } \\
\text { Value }\end{array}$ & $\begin{array}{c}\text { The Resulting Form of } \\
\text { Practice }\end{array}$ \\
\hline 1. & Mutual help & $\begin{array}{c}\text { Sharia Accounting Practices } \\
\text { Mudharabah Principles }\end{array}$ \\
\hline 2. & $\begin{array}{c}\text { Honesty and } \\
\text { Trust }\end{array}$ & $\begin{array}{c}\text { Financial accountability reports } \\
\text { that are accurate and transparent }\end{array}$ \\
\hline 3. & $\begin{array}{c}\text { Compassion and } \\
\text { Love }\end{array}$ & $\begin{array}{c}\text { Social-oriented profit sharing } \\
\text { allocation }\end{array}$ \\
\hline \multicolumn{2}{|c}{ Source: Processed data } \\
\hline
\end{tabular}

The resulting value is summarized in table 1 based on the results of research tracing, the values of mutual assistance are manifested in the sharia accounting practice of the mudharabah principles. The principle by which humans enable efforts to develop their assets as well as an affirmation of the necessity of helping each other. The values of honesty and trust are manifested in the form of financial reporting and accountability which emphasizes the importance of accounting information which has the ability to influence users to behave ethically in doing business in order to maintain the brotherhood that exists in business partners. The values of compassion and love as the supplementation of accounting spiritual values that can balance its masculine character, nudge the selfishness of accounting which is colored by its capitalistic nature, the benefits that are obtained are not only for individual prosperity but consider the interests of the general public. If you describe the benefits that are born from ukhuwah-based accounting attached to the sharia-based business entity 212 Mart Al-Fatih, as follows:

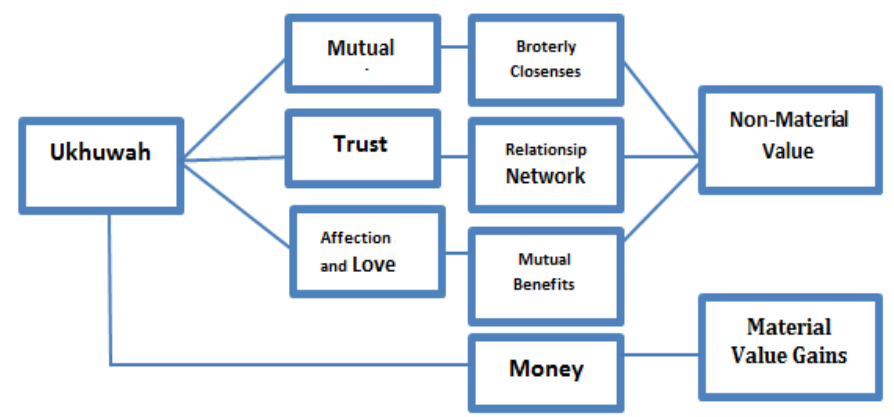

Fig 1:- Schema 1.1 profit scheme on a ukhuwah basis

This Fig shows that profit in the view of the community 212 consists of material values and in nonmaterial forms. Profits in non-material values are expressed through help, trust and affection and love, all of which are interwoven as a brotherly attitude that will reap blessings. Bringing them as human beings at the center of awareness of the importance of accounting which is more humanist in value.

Conventional accounting practices today often place accounting people as rational beings who always want to maximize their personal benefits and ignore ethical and moral issues, the environment, others, and religious rules. Such accounting practices are laden with acts of fraud, dishonesty, injustice, and purely materialistic. These practices arise because of the conceptions that have been expressed in the world of accounting about the orientation to be achieved in accounting practice itself, namely profit maximization (profit oriented). In such conditions, ethical, moral, and religious values are undoubtedly needed in the world of accounting. Various literatures that tend to criticize conventional accounting practices want to put ethical, moral, and religious values as the spirit for accounting practice. Social and cultural practices in accounting emerge in two aspects: first, through the moral and ethical standards of individual accounting actors and the accounting regulations and standards that are made. Second, ethics, morals, and religion (spirituality) can be used as the spirit of accounting in the accounting learning process in existing educational institutions. Thus, both accounting and standard actors can bring up accounting practices that prioritize human interests in general, the universe based on divine values.

At this moment, the role of Islamic accounting as a subject is influenced by its reality and environment. When humans feel themselves consciously that they are able to escape the various shackles of capitalism slowly by trying to think positively that there are social values and spirituality as the single greatest wealth which is priceless to be able to free themselves from all the things that hold them back. Sylvia (2014) provides an example of efforts 
full of social values by accounting academics and practitioners to balance materialist accounting by bringing ethical, moral, spirituality, local culture, and altruism values into accounting. In the realm of shackling, accounting standard makers who are supposed to regulate sound accounting practices have not yet fully considered the interests of the general public but rather accommodate the interests of companies whose standard formulation of results is always directed by the standard setting board. Therefore, a greater awareness is needed to be able to present balancing values for accounting so that it does not only stand above the interests of the giver of capital but is also more humanist and spiritual in nature. Social values will make accounting empathize with stakeholders, not materialistic accounting but to carry out accounting to reach divine pleasure.

\section{CONCLUSION}

The conclusion of this research is to look more deeply at the sharia accounting practices adopted by them (212 Mart Al-Fatih Villa Mutiara), which are strongly applied in terms of Ukhuwah values. This is because there are new ideas behind the practice of Islamic accounting that have been implemented so far, the highlight can be seen in the value of ukhuwah such as solidarity that is built between people with the patterns of thought and belief that is held. So from there it can be concluded that the Islamic accounting practice there is based on ukhuwah because it contains the values of help, trust, compassion and love. Thus, accounting practices should be based on the value of ukhuwah, because ukhuwah is seen as a solution to unhealthy practices so far. Healthy accounting practices based on ukhuwah values are a necessity for a business world that is dry with values and is hit by a humanitarian crisis in this era. The form of ukhuwah-based sharia accounting practice can be said to be a new accounting prototype that was born from Indonesia that can enrich management accounting forms as well as in the realm of financial accounting. Ukhuwah-based accounting practice as financial accounting is a consequence of the development of elements of the ukhuwah cultural tradition which involves all parties who are members of 212 Mart Al-Fatih Villa Mutiara.

The meaning of ukhuwah-based sharia accounting practice is an integration of 3 meanings that have been found which form a unified meaning, the three meanings, namely, help, trust, affection and love. Ukhuwah is the epicenter of business culture dynamics and innovation at the 212 Mart Al-Fatih business entity. Ukhuwah means not just brotherhood, but a close socio-economic bond that has a significant effect on the achievement of community progress, ukhuwah is expressed in community attitudes and behaviors that are cohesive, mutual help, mutual trust, spread love and love for others. Because awareness and concern to serve common interests is emphasized. Likewise, honesty becomes the first pillar of a person in conducting business and accounting activities, because it guarantees trust, to be chosen and carried out. Also to maximize the use of the goals of the brotherhood itself.
If ukhuwah is juxtaposed with modern accounting today, accounting can be a record that is in accordance with the true value without any engineering, moral hazard. For the sake of maximizing personal gain, so in this case there are no more cases of manipulation. Thus, accounting practice should be based on the value of ukhuwah, because ukhuwah is seen as a solution to unhealthy practices so far. Healthy accounting practices based on ukhuwah values are a necessity for a business world that is dry with values and is hit by a humanitarian crisis in this era.

\section{REFERENCES}

[1]. Abdul, Ghoffar M. 2004. Tafsir Ibnu Katsir, Bogor: Pustaka Imam Asy-syafi'i Al-Quran and its Translation. 2008. Ministry of Religious Affairs. Bandung: Diponegoro.

[2]. Alimuddin. 2011. Islamic Pricing Concept Based On Ukhuwa Value. International Seminar And Confrence On Islamic Economics: Bridging Ideal And Realities Toward Economic Development Sustainability In Emerging Islamics Countries: Islamic Economic In Macro And Micro Perspective. Jakarta State University And Darul Ridzuan Islamic CollegeMalaysia, 11-12 October 2010, Jakarta.

[3]. Bungin M. B. (2007). Qualitative Research: Communication, Economics, Public Policy, and Other Social Sciences. Jakarta: Prenada Media Group

[4]. Creswell, J. W. (2013). Qualitative Research and Research Design: Choosing Among Five Approaches 3rd Edition. In A. L. Lazuardi. Yogyakarta: Yogyakarta: Student Library.

[5]. Garfinkel, Harold. 2010. Ethnometodhology Approach. Sage Publication

[6]. Joubishet al. (2011). Paradigms and Characteristics of a Good Qualitative Research. World Applied Science Journal, 12 (11): 2082-2087.

[7]. Kuntowijoyo, 1991. Islamic Paradigm "Interpretation for Action". Bandung: Mizan

[8]. Ludigdo, Hanif. 2015. Accounting for Profit Sharing System of Mato Ethnography in Padang Restaurant Business. Jakarta: Mitra Wacana Media

[9]. Morgan, garet. 1998. Accounting as realty Construction Toward a new epistemology for accounting practice. Accounting Organization and Society 13 (5)

[10]. Musdiana, Roamh Niah. 2015. The Effectiveness of Mudharabah Financing in Improving the performance of UMKM. Case Study at BMT Nurul Jannah Gresik) Journal of Islamic Economics and Business Vol. 1, No. 1

[11]. Sylvia. 2014. Brings Love To Accounting. Journal of Multiparadigma Accounting (JAMAL). Volume 5, Number 1.Page: 1-160. Malang, April.

[12]. Triyuwono, Iwan. 1996. Accounting theory dealing with Islamic values. Journal of Ulumul Qur'an. Vol. VI. No.5 